\title{
Revisiting the concept of longitudinal gradients in reservoirs
}

\author{
Revisitando o conceito de gradientes longitudinais em reservatórios
}

\section{Fernanda Melo Carneiro ${ }^{1^{*}}(\mathbb{D})$ and Luis Mauricio Bini $^{2}$}

${ }^{1}$ Instituto de Ciências Biológicas e Saúde, Universidade Estadual de Goiás - UEG, Campus Metropolitano, Unidade Universitária de Goiânia, Laranjeiras, Goiânia, GO, Brasil

${ }^{2}$ Departamento de Ecologia, Instituto de Ciências Biológicas, Universidade Federal de Goiás - UEG, Campus Samambaia, Goiânia, GO Brasil

*e-mail: fernanda.carneiro@ueg.br

Cite as: Carneiro, F.M. and Bini, L.M. Revisiting the concept of longitudinal gradients in reservoirs. Acta Limnologica Brasiliensia, 2020, vol. 32, e8.

\begin{abstract}
Aim: Reservoirs are an increasingly common type of aquatic ecosystem in countries where hydropower is a dominant energy source. Understanding the functioning of these systems is essential to establish monitoring strategies or priorities for their use. The main goal of this study was to test for the presence of longitudinal gradients in reservoirs. Methods: We gathered data along the main axes of 17 tropical reservoirs to test the relationship between different ecological indicators (e.g., turbidity, nutrient concentrations, and phytoplankton abundance) and distance to the dam. After, we tested whether the strengths of longitudinal gradients were related to a set of explanatory variables (occurrence in a reservoir cascade, presence of tributaries near the dam, land-use, morphology and reservoir age). Results: We did not find significant relationships between our set of ecological indicators and distance to the dam and the strengths of these relationships were not consistently predicted by the explanatory variables. However, different indicators suggested patterns consistent with expectations. Conclusion: The distance to the dam is not a consistent predictor of the spatial variation of different limnological variables in tropical reservoirs, highlighting a high degree of context-dependency.
\end{abstract}

Keywords: reservoir zonation; hydroelectric; phytoplankton; nutrients; monitoring.

Resumo: Objetivo: Os reservatórios são um tipo cada vez mais comum de ecossistema aquático em países onde a energia hidrelétrica é uma fonte de energia dominante. A compreensão do funcionamento desses sistemas é essencial para estabelecer estratégias de monitoramento e prioridades de uso. O principal objetivo deste estudo foi testar se diferentes indicadores ecológicos apresentavam gradientes longitudinais em reservatórios. Métodos: Coletamos dados ao longo dos eixos principais de 17 reservatórios tropicais para testar a relação entre diferentes indicadores ecológicos (por exemplo, turbidez, concentraçôes de nutrientes e abundância do fitoplâncton) e a distância da barragem. Depois, testamos se as magnitudes dos gradientes longitudinais estavam relacionadas a um conjunto de variáveis explanatórias (ocorrência de reservatórios em cascatas, presença de tributários próximos à barragem, uso do solo, morfologia e idade do reservatório). Resultados: Não encontramos relações significativas entre nosso conjunto de indicadores ecológicos e a distância da barragem e as magnitudes dessas relaçóes não foram consistentemente previstas pelas variáveis explanatórias. No entanto, diferentes indicadores exibiram padrôes consistentes com as expectativas. Conclusão: A distância da barragem não é um preditor consistente da variabilidade espacial de diferentes variáveis limnológicas em reservatórios tropicais, destacando um alto grau de dependência do contexto.

Palavras-chaves: zonas de reservatórios; hidroelétrica; fitoplâncton; nutrientes; monitoramento. 


\section{Introduction}

Thornton et al. (1981) proposed a conceptual model to describe the spatial patterns of different limnological variables along the main axis of a reservoir. According to this model, water velocity decreases from upstream to downstream reaches (near the dam), with consequent increases in sedimentation rates and water transparency. As a result, one would find three zones, with different water characteristics, along the main axis of a reservoir: riverine, transition and lacustrine. The idealized model also predicts a phytoplankton biomass peak at the transition zone because the riverine and lacustrine zones are likely to be light- and nutrient-limited, respectively (Kimmel et al., 1990).

The heurist model proposed by Thornton et al. (1981) has different implications. For example, the patterned variation in different limnological variables (e.g., water transparency, nutrient concentrations and phytoplankton biomass) may be related to the formation of other biological gradients (Rodrigues \& Bicudo, 2001; Okada et al., 2005; Draštík et al., 2008; Pamplin et al., 2006; Rychtecký $\&$ Znachor, 2011). Also, in an applied context, the sampling frequency for water quality monitoring purposes should consider the variation in the risk of algal blooms among the zones (Forbes et al., 2008). However, different factors may influence the formation of longitudinal gradients in reservoirs, including morphometric characteristics, watershed land use, hydrological variation, reservoir age, presence of upstream reservoirs and the geographical position of tributaries (Kennedy \& Walker, 1990; Straškraba et al. 1993; Sabater et al., 2008; Šimek et al., 2011; Liu et al., 2012; see Table 1). Thus, studies on different scales and in a variety of geographical contexts are necessary to assess the general applicability of the model.

Here, our general goal was to test for the presence of longitudinal gradients in 17 tropical reservoirs. Physical, chemical and biological (phytoplankton) characteristics were used as response variables, whereas the distance between the sampling sites and the dam was used as the explanatory variable. We predicted that turbidity and nutrient concentrations should increase from the lacustrine to the riverine zone (positive gradient). Water transparency should exhibit the inverse pattern. We also expected a dominance of large phytoplankton cells in the lacustrine zone (Reynolds, 2006). As for the main phytoplankton groups, we predicted a high abundance of Zygnemaphyceae in the lacustrine zones because species from this class tend to be associated with oligotrophic waters. On the other hand, Bacillariophyceae should be more abundant in the riverine zones because of its association with lotic systems (Rychtecký \& Znachor, 2011). Finally, we also predicted that different factors should influence the strength of the longitudinal gradients in reservoirs (see summary in Table 1).

\section{Material and Methods}

\subsection{Data Sampling}

We collected water samples from 17 reservoirs in three hydrographic basins in the State of Goiás (Figure 1, Table 2). Sampling was conducted during July 2009, a dry-season period. Depending on the size of the reservoir, between 3 and 6 sites were sampled along the main axis of each reservoir (Figure 1).

Basic limnological variables (turbidity, water transparency and conductivity) were measured in the field using standard equipment (turbidimeter, Secchi disk and conductivimeter). Water samples were analyzed for chlorophyll-a, total phosphorus and total nitrogen concentrations following the methods of collection, storage and determination described in APHA (2005).

We collected subsurface phytoplankton samples (ca. $40 \mathrm{~cm}$ depth) for the quantitative analyses. After,

Table 1. Brief description of how different factors are expected to change the longitudinal gradients in reservoirs.

\begin{tabular}{|c|c|}
\hline Factor & Predictions (and supporting references, when available) \\
\hline Age & Reservoir recently created should exhibit less pronounced longitudinal gradients (Jorcin \& Nogueira, 2008). \\
\hline Land-Use & $\begin{array}{l}\text { An increase in agriculture and cattle ranching in the watershed should decrease the strengths of the } \\
\text { longitudinal gradients because these activities increase diffuse nutrient loading (in different regions of a } \\
\text { reservoir), blurring the gradient (Espíndola et al., 2000; Karatayev et al., 2005). }\end{array}$ \\
\hline Morphology & $\begin{array}{l}\text { More dendritic reservoirs (e.g., high shoreline development) with complex hydrological dynamics should } \\
\text { have less pronounced longitudinal gradients (Straškraba et al., 1993). }\end{array}$ \\
\hline Tributaries & $\begin{array}{l}\text { The presence of tributaries nearby the lacustrine zones of reservoirs should interfere with the formation } \\
\text { of longitudinal gradients (Rice et al., 2001). }\end{array}$ \\
\hline Cascades & $\begin{array}{l}\text { Longitudinal gradients in isolated reservoirs should differ from those observed in reservoir cascade (Tundisi } \\
\text { \& Matsumura-Tundisi, 2003; Draštík et al., 2008). }\end{array}$ \\
\hline
\end{tabular}




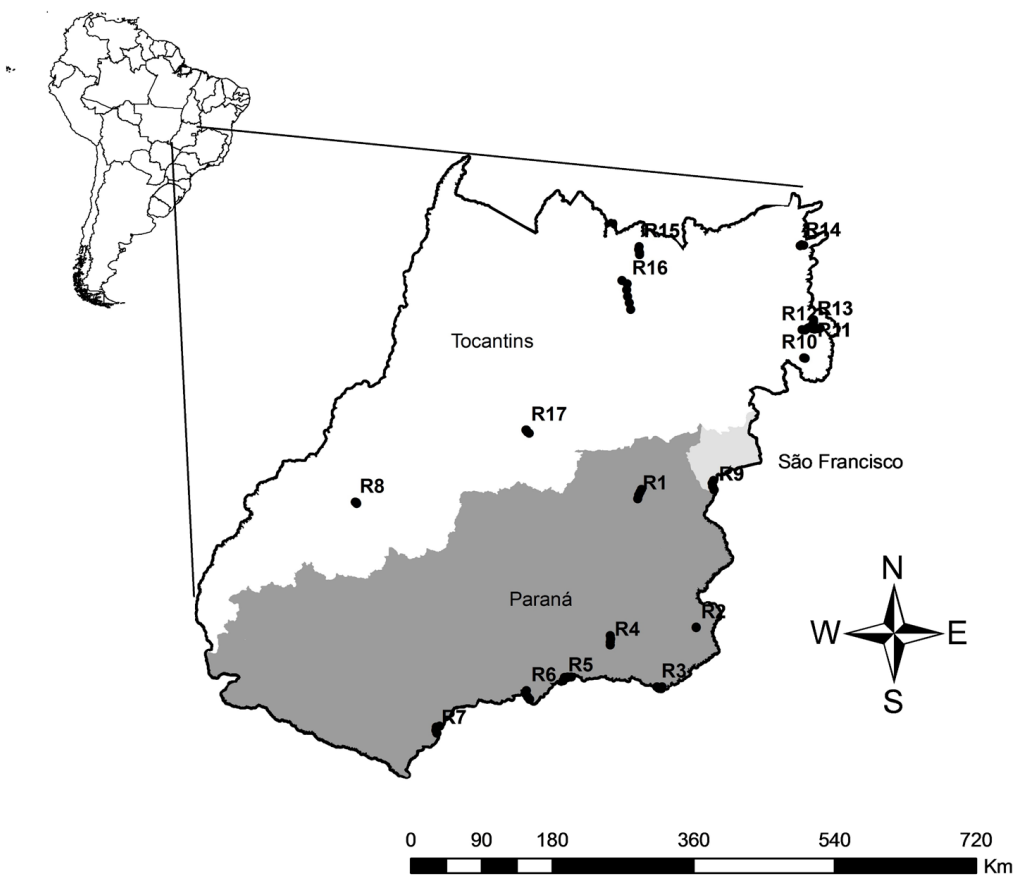

Figure 1. Geographical locations of the 17 reservoirs sampled in the State of Goiás in Paranaíba (R1 to R7), São Francisco (R9) and Araguaia-Tocantins basins (R8, R10, R11, R12, R13, R14, R15, R16 R17).

Table 2. Mean values of abiotic variables in the reservoirs. See Figure 1 for the localization of the reservoirs.

\begin{tabular}{|c|c|c|c|c|c|}
\hline & $\begin{array}{l}\text { Turbidity } \\
\text { (NTU) }\end{array}$ & $\begin{array}{c}\text { Water } \\
\text { Transparency }(m)\end{array}$ & $\begin{array}{c}\text { Conductivity } \\
(\mu \mathrm{S} / \mathrm{cm})\end{array}$ & $\begin{array}{c}\text { Total Phosphorus } \\
\left(\mu \mathrm{g} \mathrm{I}^{-1}\right)\end{array}$ & $\begin{array}{c}\text { Total Nitrogen } \\
\left(\mu \mathrm{g}^{-1}\right)\end{array}$ \\
\hline R1 & 2.03 & 3.63 & 45.35 & 2.83 & 1021.14 \\
\hline R2 & 1.8 & 4.88 & 3.19 & 1 & 355.35 \\
\hline R3 & 1.83 & 4.54 & 31.63 & 1.77 & 355.82 \\
\hline R4 & 1.53 & 5.12 & 38.25 & 4.3 & 504.05 \\
\hline R5 & 1.1 & 6.01 & 33.05 & 2.16 & 391.36 \\
\hline R6 & 1.9 & 4.21 & 32.7 & 2.46 & 450.43 \\
\hline $\mathrm{R7}$ & 1.31 & 5.76 & 44.2 & 2.65 & 510.28 \\
\hline $\mathbf{R 8}$ & 10.09 & 1.23 & 38.2 & 12.22 & 384.82 \\
\hline R9 & 1.25 & 5.28 & 46 & 1.35 & 431.5 \\
\hline R10 & 2.41 & 3.3 & 18.57 & 2.03 & 387.71 \\
\hline R11 & 1 & 3.94 & 18.27 & 3.17 & 434.65 \\
\hline R12 & 1.8 & 3.68 & 41 & 7.99 & 325.54 \\
\hline R13 & 1.71 & 3.28 & 33.4 & 7.72 & 364.72 \\
\hline R14 & 1.25 & 5.88 & 3.99 & 3.6 & 280.68 \\
\hline R15 & 0.77 & 5.65 & 73.48 & 1.25 & 322.67 \\
\hline R16 & 0.75 & 6.63 & 92.2 & 2.22 & 365.47 \\
\hline R17 & 8.86 & 1.57 & 64 & 11.22 & 594.24 \\
\hline
\end{tabular}

these samples were stored in 100-ml dark bottles and fixed with Lugol's solution. Phytoplankton density was estimated according to Utermöhl (1958), with a Zeiss inverted microscope. Organisms were usually identified to the species level and the phytoplankton classes were defined according to Van der Hoek et al. (1995). We measured the greatest axial linear dimension (GALD) of phytoplankton species in each site according to Reynolds (1984).
We used a Geographic Information System (ESRI spatial analysis) to measure the area and perimeter of each reservoir. The shoreline development index $\left(\mathrm{SL}_{\mathrm{D}}\right)$ was calculated following the methods described in Wetzel \& Likens (2000). We used digital data from the Shuttle Radar Topography Mission (SRTM) to determine the drainage area of each reservoir (Jarvis et al., 2008). Land use data (from PROBIO: Projeto de 
Conservação e Utilização Sustentável da Diversidade Biológica; www.sieg.go.gov.br; see SANO et al., 2010) were used to estimate the area of the drainage (\%) used for cattle ranching and agriculture (i.e., the sum of both land-uses). A map of the drainage basin was used to identify the presence of tributaries near the lacustrine and transition zones of the reservoirs and whether the reservoirs were positioned or not in a cascade. Reservoirs were divided into two groups according to these characteristics: with and without tributaries near the dam and isolated and in a cascade. Data on reservoir age were obtained from the National Water Resources Information System (ANA, 2020).

\subsection{Data analysis}

We used linear mixed-effects models (LMM) to quantity the strength of the relationship between each limnological variable and the distance to the dam (Zuur et al., 2009). For this, we used the "lme" function from the package "nlme" in the R program (Bates \& Pinheiro 1998) and included reservoir identity as a random effect in the models. In a second step, we used the slopes of the models (a set for each limnological variable) as response variables (measuring the strength of the longitudinal gradients) in a multiple regression analysis. The following explanatory variables were used for this analysis: cascade (a dummy variable indicating whether the reservoir is in a cascade of reservoirs), tributary (a dummy variable indicating the presence of tributaries near the dam), reservoir age, land use and the shoreline development index $\left(\mathrm{SL}_{\mathrm{D}}\right)$. Quantitative explanatory variables were log-transformed before analysis.

\section{Results}

Reservoirs were highly heterogeneous both in terms of abiotic (Table 2) and biotic characteristics (Table 3). In general, we recorded high water transparency (up to $6.6 \mathrm{~m}$ ) and low trophic level (maximum chlorophyll-a concentration of $1.84 \mu \mathrm{g} . \mathrm{l}^{-1}$; Tables 2 and 3). Cyanophyceae and Chlorophyceae were the most abundant classes. Watersheds ranged from those with low land use ( $0.4 \%$ of the area) up to those highly impacted by agriculture and cattle ranching activities (99.73\%). We sampled reservoirs that were recently formed (1-year-old) up to reservoirs that were created 54 years ago and reservoirs with low shoreline complexity up to very dendritic reservoirs. Most of the reservoirs have tributaries debouching near the dam (13) and are inserted in cascades (11; Table 4).

The relationships between the response variables and distance to the dam were not significant (Table 5). The analysis of the fitted values for the community (from LMM) suggested "positive"

Table 3. Mean values of chlorophyll-a (Chl-a), phytoplankton species richness, greatest axial linear dimension (GALD), total density and densities of Zygnemaphyceae (Zygn), Bacillariophyceae (Baci), Cyanophyceae (Cyan), Chlorophyceae (Chlo), Cryptophyceae (Cryp) and Euglenophyceae (Eugl).

\begin{tabular}{|c|c|c|c|c|c|c|c|c|c|c|}
\hline \multirow{2}{*}{ 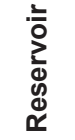 } & Chl-a & \multirow{2}{*}{ 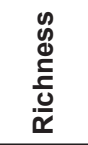 } & \multirow{2}{*}{$\frac{\text { Density }}{\left(\text { Ind. } \mathrm{ml}^{-1}\right)}$} & \multirow{2}{*}{$\begin{array}{c}\text { GALD } \\
(\mu \mathrm{m})\end{array}$} & \multirow{2}{*}{$\frac{\text { Zygn }}{(\text { Ind.ml-1) }}$} & \multirow{2}{*}{$\frac{\text { Baci }}{(\text { Ind.ml-1) }}$} & \multirow{2}{*}{$\frac{\text { Cyan }}{\left(\text { Ind. } \mathrm{ml}^{-1}\right)}$} & \multirow{2}{*}{$\frac{\text { Chlo }}{(\text { Ind.ml-1) }}$} & \multirow{2}{*}{$\frac{\text { Cryp }}{(\text { Ind.ml-1) }}$} & \multirow{2}{*}{$\frac{\text { Eugl }}{(\text { Ind.ml-1) }}$} \\
\hline & $\left(\mu \mathrm{g} . \mathrm{I}^{-1}\right)$ & & & & & & & & & \\
\hline R1 & 0.43 & 53.75 & 1385 & 20.4 & 18 & 155 & 348 & 284 & 171 & 37 \\
\hline $\mathrm{R} 2$ & 0.13 & 19.67 & 519 & 10.2 & 16 & 42 & 119 & 104 & 95 & 19 \\
\hline R3 & 1.04 & 27.5 & 684 & 16.7 & 12 & 31 & 171 & 138 & 79 & 46 \\
\hline $\mathrm{R} 4$ & 1.22 & 42.75 & 2011 & 18.1 & 18 & 104 & 223 & 543 & 565 & 20 \\
\hline R5 & 0.5 & 23.75 & 419 & 19.8 & 1 & 4 & 73 & 94 & 56 & 0 \\
\hline $\mathrm{R} 6$ & 0.13 & 10.25 & 272 & 16.4 & 3 & 15 & 24 & 53 & 11 & 0 \\
\hline $\mathrm{R} 7$ & 0.75 & 19.5 & 555 & 15.1 & 28 & 74 & 89 & 49 & 122 & 0 \\
\hline $\mathrm{R} 8$ & 0.83 & 19.67 & 504 & 28.5 & 0 & 7 & 14 & 207 & 60 & 3 \\
\hline R9 & 0.43 & 20 & 951 & 15.3 & 120 & 15 & 260 & 168 & 106 & 0 \\
\hline R10 & 0.04 & 8.67 & 35 & 38.1 & 190 & 9 & 1 & 5 & 4 & 0 \\
\hline R11 & 0.52 & 24 & 387 & 18 & 84 & 3 & 38 & 126 & 9 & 4 \\
\hline R12 & 1.13 & 27.33 & 1844 & 31.5 & 20 & 7 & 1165 & 260 & 61 & 3 \\
\hline R13 & 1.84 & 24.33 & 1397 & 15.8 & 59 & 121 & 94 & 289 & 81 & 9 \\
\hline R14 & 0.08 & 10.67 & 62 & 23.3 & 325 & 209 & 4 & 31 & 5 & 0 \\
\hline R15 & 0.6 & 42.5 & 2934 & 39.8 & 132 & 95 & 1911 & 622 & 40 & 3 \\
\hline R16 & 0.93 & 51.17 & 2282 & 27.7 & 2 & 24 & 692 & 979 & 13 & 0 \\
\hline R17 & 0.23 & 20 & 235 & 25 & 0 & 0 & 42 & 82 & 60 & 0 \\
\hline
\end{tabular}


Table 4. Explanatory variables used in this study. $\mathrm{SL}_{\mathrm{D}}$ : shoreline development index.

\begin{tabular}{cclccc}
\hline Reservoir & Land-use (\%) & SD $_{\mathbf{L}}$ & Age (years) & Tributary & Cascade \\
\hline R1 & 84.31 & 6.67 & 4 & 1 & 1 \\
R2 & 9.39 & 0.08 & 6 & 0 & 0 \\
R3 & 45.03 & 6.31 & 27 & 1 & 1 \\
R4 & 77.8 & 4.8 & 12 & 1 & 1 \\
R5 & 56.13 & 6.31 & 29 & 0 & 1 \\
R6 & 56.23 & 3.24 & 51 & 1 & 1 \\
R7 & 60.64 & 4.58 & 31 & 1 & 1 \\
R8 & 74 & 0.08 & 7 & 0 & 0 \\
R9 & 11.85 & 4.91 & 5 & 1 & 0 \\
R10 & 2.22 & 0.1 & 2 & 0 & 0 \\
R11 & 0.4 & 0.15 & 3 & 1 & 1 \\
R12 & 1.03 & 0.2 & 1 & 1 & 1 \\
R13 & 0.5 & 0.14 & 3 & 1 & 1 \\
R14 & 7.66 & 1.71 & 19 & 1 & 0 \\
R15 & 47.67 & 4.61 & 7 & 1 & 1 \\
R16 & 49.11 & 7.84 & 13 & 1 & 0 \\
R17 & 99.73 & 0.2 & 54 & 1 & \\
\hline
\end{tabular}

Table 5. Results from linear mixed effects models (LMM) quantifying the strength of the relationship between each limnological variable and the distance to the dam.

\begin{tabular}{lrcc}
\hline \multicolumn{1}{c}{ Response variables } & Intercept & Distance to the Dam & $\boldsymbol{P}$ \\
\hline Turbidity & 0.654 & 0.014 & 0.457 \\
Water transparency & 0.401 & 0.024 & 0.037 \\
Conductivity & 5.547 & 0.092 & 0.605 \\
Total Phosphorus & 0.977 & 0.698 & 0.290 \\
Total Nitrogen & 46.769 & 11.819 & 0.463 \\
Chlorophyll-a & 0.125 & 0.011 & 0.596 \\
Phytoplankton richness & 2.951 & 0.277 & 0.422 \\
Total density & 216.835 & 30.880 & 0.400 \\
GALD & 2.237 & 0.179 & 0.958 \\
Zygnemaphyceae & 21.613 & 1.124 & 0.142 \\
Bacillariophyceae & 14.124 & 2.209 & 0.082 \\
Cyanophyceae & 149.314 & 17.297 & 0.949 \\
Chlorophyceae & 52.168 & 6.391 & 0.834 \\
Cryptophyceae & 23.123 & 2.694 & 0.267 \\
Euglenophyceae & 5.311 & 0.763 & 0.916 \\
\hline
\end{tabular}

longitudinal gradients of chlorophyll-a, nutrients, phytoplankton species richness, densities of different phytoplankton classes (Bacillariophyceae, Chlorophyceae, Chlorophyceae, Cryptophyceae and Euglenophyceae) and total density of phytoplankton (Figure 2). A "negative" longitudinal gradient (a decrease of a variable towards the riverine zone) was found only for the density of Zygnemaphyceae and, to a less extent, for Cyanophyceae. Less pronounced gradients were observed for mean phytoplankton size, turbidity, conductivity, $\mathrm{pH}$ and nitrate (Figure 2).

We found that the strength of the longitudinal gradient of total phosphorus was negatively related with shoreline development and positively related to land use and the presence of tributaries. Thus, the higher the shoreline development, the lower the longitudinal gradient of total phosphorus and, contrary to our predictions, the strength of the gradients increased with land use and the presence of tributaries. The strength of the gradient in species richness decreased with reservoir age and increased with land use. The strength of the gradient in Chlorophyceae density increased with reservoir shoreline development. The strength of the gradient in Bacillariophyceae density decreased with reservoir age and increased with land use. The gradient strengths of the of the other response variables were unrelated to our explanatory variables (Table 6). 

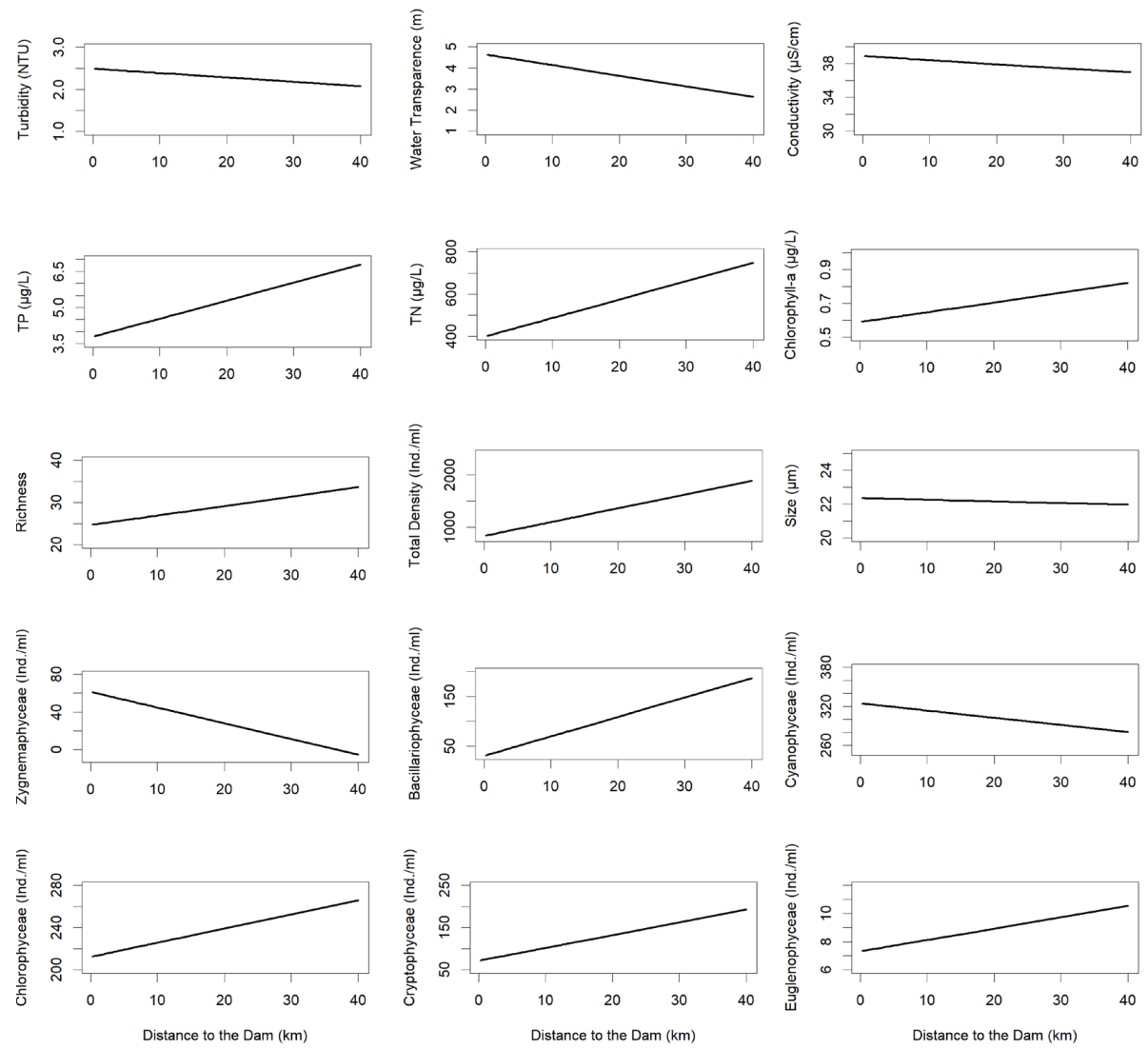

Figure 2. Relationships between response variables and distance to the dam. Shown are the fitted population curves from linear mixed models.

Table 6. Multiple regressions between the longitudinal trends for each variable (slope) tested in the linear mixed regression and the explanatory variables such as age, land-use, shoreline development index $\left(\mathrm{SL}_{\mathrm{D}}\right)$, tributary, and cascade.

\begin{tabular}{lcccccc}
\hline & $\mathbf{R}_{\text {adj }}$ & Age & Land-use & $\mathbf{S L}_{\mathbf{D}}$ & Tributary & Cascade \\
\hline Turbidity & -0.333 & $<0.001$ & $<0.001$ & $<0.001$ & $<0.001$ & $<0.001$ \\
Water Transparency & 0.149 & -0.133 & -0.056 & 0.703 & -0.125 & -0.364 \\
Conductivity & 0.278 & -0.204 & 0.354 & 0.568 & 0.043 & -0.483 \\
Total Phosphorus & $\mathbf{0 . 7 3 8}$ & -0.267 & $\mathbf{0 . 5 1 5}$ & $\mathbf{- 1 . 0 2}$ & $\mathbf{0 . 4 2 1}$ & -0.027 \\
Total Nitrogen & -0.004 & -0.501 & 0.481 & 0.109 & 0.039 & -0.046 \\
Chlorophyll-a & 0.329 & -0.435 & 0.006 & -0.546 & -0.003 & 0.449 \\
Richness & $\mathbf{0 . 5 9 6}$ & $\mathbf{- 0 . 5 6 6}$ & $\mathbf{0 . 7 4 9}$ & 0.263 & 0.054 & 0.136 \\
Density & -0.075 & -0.347 & 0.297 & 0.29 & 0.108 & -0.194 \\
GALD & -0.231 & 0.283 & -0.285 & 0.123 & 0.016 & 0.052 \\
Zygnemaphyceae & -0.048 & -0.075 & -0.102 & 0.516 & 0.052 & -0.08 \\
Bacillariophyceae & $\mathbf{0 . 4 3 8}$ & $\mathbf{- 0 . 7 7 1}$ & $\mathbf{0 . 8 7 1}$ & -0.053 & 0.092 & -0.004 \\
Cyanophyceae & -0.003 & -0.064 & 0.205 & 0.417 & -0.042 & -0.397 \\
Chlorophyceae & $\mathbf{0 . 4 6 2}$ & -0.304 & 0.422 & $\mathbf{0 . 6 1 3}$ & 0.003 & -0.124 \\
Cryptophyceae & 0.221 & -0.549 & 0.648 & 0.067 & 0.21 & 0.05 \\
Euglenophyceae & 0.08 & -0.577 & 0.677 & -0.225 & 0.153 & -0.081 \\
\hline
\end{tabular}

\section{Discussion}

Our results are at odds with the literature showing clear longitudinal gradients in reservoirs (e.g., Bini, 1997; Rodrigues \& Bicudo, 2001; Velho et al., 2001; Okada et al., 2005; Pamplin et al., 2006; Prchalová et al., 2008). We cannot discard the possibility that our small sample size (within each reservoir) precluded the detection of gradients. Also, a snapshot sampling may not be enough and, therefore, long-term average values should be used to test for the occurrence of longitudinal gradients in reservoirs. However, it is remarkable 
that the undeniable effects of the unidirectional flow (from upstream to downstream reaches) passed undetected.

Despite the lack of statistical significance, some of the gradients were in the expected direction (e.g., water transparency and nutrient concentration). Interestingly, gradients in the density of major phytoplankton groups were also in the expected direction. For example, Zygnemaphyceae decreased in density from the lacustrine to the riverine zone, and Bacillariophyceae increased in density in the same direction. Desmids (Zygnemaphyceae) are known to thrive in environments with low nutrient concentrations (Rodrigues \& Bicudo, 2001; Caputo et al., 2008) and in the lacustrine zone of reservoirs (Rychtecký \& Znachor, 2011), whereas diatoms (Bacillariophyceae) are usually associated with turbulent waters (Reynolds, 1994; Reynolds, 2006; Wang et al., 2011). The decrease in the abundance of Cyanophyceae towards the riverine zone highlights the importance of hydrological conditions to control this group of algae (Nogueira et al., 2010). In general, an increase in the abundance of other algal groups towards the riverine zone (e.g., see results for Chlorophyceae, Cryptophyceae and Euglenophyceae and for the total phytoplankton abundance and species richness) is consistent with the view that upstream reaches are important sources of taxa contributing, via drift, to plankton diversity in reservoirs (Lopes et al., 2019).

As expected, the longitudinal gradient of total phosphorus was reduced in more dendritic reservoirs. However, contrary to our predictions, land use and the presence of tributaries near the dam influenced positively the total phosphorus gradient. Initially, we expected that an increase in agriculture and cattle ranching in the watershed should decrease the strengths of the longitudinal gradients because these activities increase diffuse nutrient loading (in different regions of a reservoir), blurring the gradient (Espíndola et al., 2000; Karatayev et al., 2005). A positive relationship between the strength of the gradient in total phosphorus and land use may, however, be explained if diffuse nutrient loading occurs mainly in upstream reaches of the watershed. Similarly, we initially predicted that an increase in total phosphorus concentration near the dam, due to the enriched waters of tributaries, would flatten the longitudinal gradient. Instead, we found a positive effect of tributaries. This result suggests that the tributaries promoted a dilution effect, which in turn, increased the strength of the gradient. Also, the other models showing significant results (for species richness, Bacillariophyceae and Chlorophyceae) indicated patterns contrary to what we expected. Finally, the other models were not statistically significant, indicating that our explanatory variables (land use, age, shoreline development, etc.) were not important to predict the strengths of the longitudinal gradients of most of the variables (e.g., turbidity, total phytoplankton abundance, and chlorophyll-a). Cascade reservoirs are characterized by a shorter water residence time and consequently less-defined zonation (Barbosa et al., 1999; Draštík et al., 2008). Thus, it is surprising that this explanatory variable was unimportant for the different gradients tested.

The results of this study indicated that longitudinal gradients in tropical reservoirs are not as ubiquitous as previously thought (see also Bernot et al., 2004; Borges et al., 2008; Becker et al., 2016). They also indicated that the strengths of these gradients were not easily predictable. Thus, we suggest that distance to the dam is a poor predictor of reservoir zonation. For biomonitoring purposes, we suggest an intensive sampling program instead of allocating a few sampling sites along the main axes of reservoirs.

\section{Acknowledgements}

Fernanda M. Carneiro has been supported by BIP UEG productivity fellowship. Luis M. Bini has been supported by CNPq productivity fellowships.

\section{References}

AGÊNCIA NACIONAL DE ÁGUAS - ANA. SISTEMA NACIONAL DE INFORMAÇÓES SOBRE OS RECURSOS HÍDRICOS. Portal HidroWeb [online]. Brasília, 2020 [viewed 20 Mar. 2020]. Available from: http://portal1.snirh.gov.br/ ana/apps/webappviewer

AMERICAN PUBLIC HEALTH ASSOCIATION - APHA. Standard methods for the examination of water and wastewater. 21st ed. Washington, DC: APHA, 2005.

BARBOSA, F.A.R., PADISÁK, J., ESPÍNDOLA, E.L.G., BORICS, G. and ROCHA, O. The Cascading Reservoir Continuum Concept (CRCC) and its Application to the River Tietê-basin, São Paulo State, Brazil. In: J.G. TUNDISI and M. STRASKRABA. Theoretical Reservoir Ecology and Its applications International Institute of Ecology. São Carlos: International Institute of Ecology, 1999, pp. 313-346.

BATES, D.M. and PINHEIRO, J.C. Computational methods for multilevel models. Murrey Hills: Bell Labs, 
1998. [viewed 20 Mar. 2020]. Available from: http:// nlme.stat.wisc.edu/pub/NLME/

BECKER, B., GALHARDO, B.O.S., MACEDO, D.R., HUGHES, R.M., CALLISTO, M. and SANTOS, G.B. Influence of limnological zone on the spatial distribution of fish assemblages in three Brazilian reservoirs. Journal of Limnology, 2016, 75(1), 156168.

BERNOT, R.J., DODDS, W.K., QUIST, M.C. and GUY, C.S. Spatial and temporal variability of Zooplankton in a great plains reservoir. Hydrobiologia, 2004, 525(1-3), 101-112. http://dx.doi.org/10.1023/ B:HYDR.0000038857.19342.fd.

BINI, L.M. Spatial variation of some limnological parameters in Barra Bonita reservoir (São Paulo, Brazil): A geostatistical approach. Verh. Internat. Verein. Limnol., 1997, 26(2), 229-231. http://dx.doi. org/10.1080/03680770.1995.11900706.

BORGES, P.A.F., TRAIN, S. and RODRIGUES, L.C. Spatial and temporal variation of phytoplankton in two subtropical Brazilian reservoirs. Hydrobiologia, 2008, 607(1), 63-74. http://dx.doi.org/10.1007/ s10750-008-9367-3.

CAPUTO, L., NASELLI-FLORES, L., ORDOÑEZ, J. and ARMENGOL, J. Phytoplankton distribution along trophic gradients within and among reservoirs in Catalonia (Spain). Freshwater Biology, 2008, 53(12), 2543-2556. http://dx.doi.org/10.1111/ j.1365-2427.2008.02082.x.

DRAŠTÍK, V., KUBEČKA, J., TUŠER, M., ČECH, M., FrOUZOVÁ, J., JAROLÍM, O. and PRCHALOVÁ, M. The effect of hydropower on fish stocks: comparison between cascade and noncascade reservoirs. Hydrobiologia, 2008, 609(1), 2536. http://dx.doi.org/10.1007/s10750-008-9393-1.

ESPÍNDOLA, E.L.G., MATSUMURA-TUNDISI, T., RIETZLER, A.C. and TUNDISI, J.G. Spatial heterogeneity of the Tucuruí Reservoir (State of Pará, Amazonia, Brazil) and the distribution of zooplanktonic species. Revista Brasileira de Biologia, 2000, 60(2), 179-194. http://dx.doi.org/10.1590/ S0034-71082000000200001. PMid:10959101.

FORBES, M.G., DOYLE, R.D., SCOTT, J.T., STANLEY, J.K., HUANG, H. and BROOKS, B.W. Physical Factors Control Phytoplankton Production and Nitrogen Fixation in Eight Texas Reservoirs. Ecosystems, 2008, 11(7), 1181-1197. http://dx.doi. org/10.1007/s10021-008-9188-2.

JARVIS, A., REUTER, H.I., NELSON, A. and GUEVARA, E. Hole-filled SRTM for the globe Version 4, available from the CGIAR-CSISRTM $90 m$ [online]. CGIAR, 2008 [viewed 20 Mar. 2020]. Available from: http://srtm.csi.cgiar.org.

JORCIN, A. and NOGUEIRA, M.G. Benthic macroinvertebrates in the Paranapanema reservoir cascade (southeast Brazil). Brazilian Journal of Biology,
2008, 68(4), 1013-1024, Supplement. http:// dx.doi.org/10.1590/S1519-69842008000500009. PMid:19197472.

KARATAYEV, A.Y., BURLAKOVA, L.E. and DODSON, S.I. Community analysis of Belarusian lakes: Relationship of species diversity to morphology, hydrology and land use. Journal of Plankton Research, 2005, 27(10), 1045-1053. http://dx.doi. org/10.1093/plankt/fbi072.

KENNEDY, R.H. and WALKER, W.W. Reservoir Nutrient Dynamics. In: K.W. THORNTON, B.L. KIMMEL and F.E. PAYNE, eds. Reservoir limnology. New York: Ecological Perspectives, 1990, pp. 109131.

KIMMEL, B.L., LIND, O.T. and PAULSON, L.J. Resevoir Primary Production. In: K.W. THORNTON, B.L. KIMMEL and F.E. PAYNE, eds. Reservoir limnology. New York: Ecological Perspectives, 1990, 133-194.

LIU, W., LI, S., BU, H., ZHANG, Q. and LIU, G. Eutrophication in the Yunnan Plateau lakes: the influence of lake morphology, watershed land use, and socioeconomic factors. Environmental Science and Pollution Research International, 2012, 19(3), 858-870. http://dx.doi.org/10.1007/s11356-0110616-z. PMid:21948141.

LOPES, V.G., BRANCO, C.W.C., KOZLOWSKYSUZUKI, B. and BINI, L.M. Zooplankton temporal beta diversity along the longitudinal axis of a tropical reservoir. Limnology, 2019, 20(1), 121-130. http:// dx.doi.org/10.1007/s10201-018-0558-y.

NOGUEIRA, M.G., FERRAREZE, M., MOREIRA, M.L. and GOUVÊA, R.M. Phytoplankton assemblages in a reservoir cascade of a large tropical-subtropical river (SE, Brazil). Brazilian Journal of Biology, 2010, 70(3), 781-793. http:// dx.doi.org/10.1590/S1519-69842010000400009. PMid:21085783.

OKADA, E.K., AGOSTINHO, A.A. and GOMES, L.C. Spatial and temporal gradients in artesanal fisheries of a large neotropical reservoir, the Itaipu Reservoir, Brazil. Canadian Journal of Fisheries and Aquatic Sciences, 2005, 62(3), 714-724. http://dx.doi. org/10.1139/f05-015.

PAMPLIN, P.A.Z., ALMEIDA, T.C.M. and ROCHA, O. Composition and distribution of benthic macroinvertebrates in Americana Reservoir (SP, Brazil). Acta Limnologica Brasiliensia, 2006, 18, 121-132.

PRCHALOVA, M., KUBECKA, J., VASEK, M., PETERKA, J., SED'A, J., JUZA, T., RIHA, M., JAROLIM, O., TUSER, M., KRATOCHVIL, M., CECH, M., DRASTIK, V., FROUZOVA, J. and HOHAUSOVA, E. Distribution patterns of fishes in a canyon-shaped reservoir. Journal of Fish Biology, 2008, 73, 54-78. 
REYNOLDS, C.S. The long, the short and the stalled: on the attributes of phytoplankton selected by physical mixing in lake san drivers. Hydrobiologia, 1994, 289(1-3), 9-14. http://dx.doi.org/10.1007/ BF00007405.

REYNOLDS, C.S. The ecology of Phytoplankton. Cambridge: Cambridge University Press, 2006, 530 p. http://dx.doi.org/10.1017/CBO9780511542145.

REYNOLDS, C.S. The ecology offreshwater Phytoplankton. Cambridge: Cambridge University Press, 1984, 384 p.

RICE, S.P., GREENWOOD, M.T. and JOYCE, C.B. Tributaries, sediment sources, and the longitudinal organisation of macroinvertebrate fauna along river systems. Canadian Journal of Fisheries and Aquatic Sciences, 2001, 58(4), 824-840. http://dx.doi. org/10.1139/f01-022.

RODRIGUES, L. and BICUDO, D.D.E.C. Similarity among periphyton algal communities in a lenticlotic gradient of the upper Paraná river floodplain, Brazil. Brazilian Journal of Botany, 2001, 24(3), 235-248. http://dx.doi.org/10.1590/S010084042001000300001 .

RYCHTECKÝ, P. and ZNACHOR, P. Spatial heterogeneity and seasonal succession of phytoplankton along the longitudinal gradient in a eutrophic reservoir. Hydrobiologia, 2011, 663(1), 175-186. http://dx.doi. org/10.1007/s10750-010-0571-6.

SABATER, S., ARTIGAS, J., DURÁN, C., PARDOS, M., ROMANÍ, A.M., TORNÉS, E. and YLLA, I. Longitudinal development of chlorophyll and phytoplankton assemblages in a regulated large river (the Ebro River). The Science of the Total Environment, 2008, 404(1), 196-206. http://dx.doi.org/10.1016/j. scitotenv.2008.06.013. PMid:18675441.

SANO, E.E., ROSA, R., BRITO, J.L.S. and FERREIRA, L.G. Land cover mapping of the tropical savanna region in Brazil. Environmental Monitoring and Assessment, 2010, 166(1-4), 113-124. http://dx.doi. org/10.1007/s10661-009-0988-4. PMid:19504057.

ŠIMEK, K., COMERMA, M., GARCÍA, J.-C., NEDOMA, J., MARCÉ, R. and ARMENGOL, $J$. The effect of river water circulation on the distribution and functioning of reservoir microbial communities as determined by a relative distance approach. Ecosystems, 2011, 14(1), 1-14. http:// dx.doi.org/10.1007/s10021-010-9388-4.
STRAŠKRABA, M., TUNDISI, J.G. and DUCAN, A.. Comparative reservoir limnology and water quality management. Netherlands: Kluwer Academic Press, 1993.

THORNTON, K.W., KENNEDY, J.H., CARROLL, W.W., WALKER, R.C., GUNKEL, R.C. and ASHBY, S. Reservoir sedimentation and water quality: An heuristic model. In: H.G. STEFAN, ed. Proceedings of the Simposium on surface water impoudments. New York: American Society Civil Engineer, 1981, pp. 654-651.

TUNDISI, J.G. and MATSUMURA-TUNDISI, $T$. Integration of research and management in optimizing multiple uses of reservoirs: the experience in South America and Brazilian case studies. Hydrobiologia, 2003, 500(1-3), 231-242. http:// dx.doi.org/10.1023/A:1024617102056.

UTERMÖHL, H. Zur vervollkomnung der quantitativen phytoplankton-methodik. Mitteilungen der Internationale Vereinigung für Theoretische und Angewandte Limnologie, 1958, 9, 1-38.

VAN DER HOEK, C., MANN, S.G. and JAHNS, H.M. Algae: An introduction to phycology. Cambridge: University of Cambridge Press, 1995, 627 p.

VELHO, L.F.M., LANSAC-TÔHA, F.A., BONECKER, C.C., BINI, L.M. and ROSSA, D.C. The longitudinal distribution of copepods in Corumbá Reservoir, State Goiás, Brazil. Hydrobiologia, 2001, 453-454, $385-$ 391. http://dx.doi.org/10.1023/A:1013194118104.

WANG, L., CAI, Q., ZHANG, M., TAN, L. and KONG, L. Longitudinal patterns of phytoplankton distribution in a tributary bay under reservoir operation. Quaternary International, 2011. 2011244(2), 280-288. http://dx.doi.org/10.1016/j. quaint.2010.09.012.

WETZEL, R.G. and LIKENS, G.E. Limnological Analysis. New York: Springer, 2000. http://dx.doi. org/10.1007/978-1-4757-3250-4.

ZUUR, A.F., IENO, E.N., WALKER, N.J., SAVELIEV, A.A. and SMITH, G.M. Mixed effects models and extensions in ecology with $R$. New York: SpringerVerlag, 2009. http://dx.doi.org/10.1007/978-0387-87458-6.

Received: 11 February 2019 Accepted: 20 March 2020

Associate Editor: Ronaldo Angelini. 